\title{
Searching for Birth Parents or Adopted Children Finding without Seeking in Romance Novels
}

\section{Mary K. Chelton}

Dr. Mary K. Chelton (mchelton@ optonline.net) is a retired professor who formerly taught at the Graduate School of Library and Information Studies, Queen's College, CUNY.

The author sends her thanks to Roberta Brody at GSLIS, Queens College, and Catherine Ross, Retired, Faculty of Information and Media Studies, University of Western Ontario, for help in shaping and revising this article.

Reference \& User Services Quarterly, vol. 57, no. 4, pp. 266-73

(c) 2018 American Library Association. All rights reserved.

Permission granted to reproduce for nonprofit, educational use.
Using concepts from Catherine Sheldrick Ross's "Finding without Seeking: The Information Encounter in the Context of Reading for Pleasure," a convenience sample of 129 romance novels about secret babies is examined to determine what information is imparted about the processes by which adoptees and birth parents search for each other.

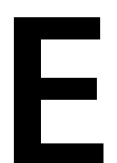

fforts by adoptees to locate their birth parents and other natal relatives form a central theme in both fiction and nonfiction adoption narratives. These efforts have a long history in the United States, where the difficulties involved in such searches were, and often still are, compounded by legally mandated confidentiality and sealed records; causing even adoptees themselves to be denied access to records such as original birth certificates after World War II. Over the same time period, search and reunion have been prominent features of adoption reform and activism, and they appear as central themes in many true adoption narratives.

One of the most familiar tropes in romance fiction is the story of the "secret baby," whose existence, when discovered, becomes the dominant barrier to be overcome in the relationship and potential commitment of the unmarried, or formerly married, parents, regardless of the manner in which the secret of the child is kept or revealed. The popularity of the stories seems to stem from the readers' love of second chances, and the opportunity to present a ready-made family as a "package deal" for the story's protagonists. ${ }^{1}$

An unknown percentage of the secret baby romance stories involves adoption. A memorable example is Emilie Richards's All Those Years Ago, in which a night school teacher falls in love with an exemplary student who he later learns dropped out of Vassar when she got pregnant. Their romance is unable to proceed until she finds the whereabouts of her adopted baby, which he helps her do.

The presence of adoption themes and issues in romance fiction inspired a study to discover if the information included was similar to or different from factual information on adoption.

\section{REVIEW OF RELEVANT LITERATURE}

\section{Information-Seeking and Fiction}

Fiction has usually not been considered a source of information in 
library-and-information information-seeking studies but more a use of casual leisure time or a source of entertainment. ${ }^{3}$ Whereas information-seeking studies have usually assumed some work- or student-related purposeful searching, studies on fiction have mostly looked at how people select the fiction they read. Their fiction selections are seen as the end result of either an information behavior process using available outside resources, a successful database search retrieval using specific indexing terms, book and genre appeal characteristics intrinsic to individual fiction works themselves sometimes converted into indexing terms, or reader-driven appeal characteristics associated with readers' social milieus. ${ }^{4}$ In other words, locating and retrieving fiction, or fulfilling readers' reading desires, is seen as more important than the factual information content found in fiction, except for Ross's work on finding without seeking. ${ }^{5}$

\section{Adoption in Literature}

Secret babies and adoption have been used as plot and character devices in literature for years, Oliver Twist being a notable example. Yet specific attention to adoption in literary texts as it intersects with culture had been sparse until the Alliance for the Study of Adoption and Culture, established in 1998, founded its journal, Adoption and Culture. The resulting literary studies emerging from members of the Alliance, such as Marianne Novy and Margaret Homans, use adoption as a lens through which to examine cultural myths and views on family and kinship. ${ }^{6}$

While these studies offer insights into how adoption is treated topically and thematically in literature, they usually ignore most popular culture texts such as romance fiction. In this genre, the unplanned pregnancy, and the secrecy surrounding it, is primarily used as a plot device to create a barrier that must be surmounted to bring the hero and heroine together, not as an examination of the deeper meanings of biological versus socially constructed kinship, or the role of adoption in society. Romance fiction does somewhat mirror the deeper cultural conflicts over adoption treated in more literary works, but through a popular culture lens constrained by genre conventions.

\section{Romance Fiction}

With the establishment of the interdisciplinary Journal of Popular Romance Studies in 2001, scholarship on romance fiction has expanded. Scholarship published in this journal includes a special section on "Romancing the Library" in 2010 and an article on romance collection development in academic libraries in 2012; however, no studies in this journal have covered adoption or secret babies.

As Regis points out, "Romance novels end happily. Readers insist on it. The happy ending is the one formal feature of the romance novel that virtually everyone can identify" and the one that elicits the fiercest criticism. ${ }^{7}$ Because of the mandated happy ending, romances are viewed as unrealistic and formulaic because in a literal sense, marriage does not necessarily mean happiness for women in real life. There is an additional issue: the question of the legitimacy of the romance novel as "literature." The sense of cultural hierarchical distinctions has plagued romance fiction to its detriment for years. ${ }^{8}$

One of the earliest studies of the appeal of romance fiction by Snitow analyzes Harlequin romances not as "art" but as "leisure activities that take the place of art" that "fill a place left empty for most people." While hardly complimentary, unlike many feminist analyses of the genre, Snitow makes several points germane to adoption as a topic for romance fiction, namely that "the books ... reflect—sometimes more, sometimes less consciously, sometimes amazingly naively-commonly experienced psychological and social elements in the daily lives of women." ${ }^{\prime 9}$ Fear of and actual unplanned pregnancies are among these elements. Snitow's categorization of reading romances as "leisure activities" also presages current studies of information seeking and casual leisure..$^{10}$

Reading the Romance is a classic study of the genre using reader response, feminist theory, and textual analysis. Through a key informant in a bookstore, Radway gains access to a cluster of romance readers and, through an analysis of their favored and unfavored titles, concludes that "the romance genre is precisely that: a genre, ... that, for a little while, assures its readers of their own self-worth and ability to affect a patriarchic world, so by the end of the novel the female readers, often mothers, feel invigorated and ready to take on the day-to-day tasks of managing the home and family." She further asserts that "it is the individual woman's choice to read romance novels, and that this selection not only fabricates a predictable, happy ending but depicts a heroine who discovers her own individuality through her ability to care for others, as opposed to unique personal qualities." ${ }^{11}$

Dangerous Men and Adventurous Women: Romance Writers on the Appeal of Romance is a collection of essays by romance writers on the genre and was compiled to refute many of the negative feminist analyses of the genre prevalent at its time of publication. It coalesces around several themes that attempt to explain the encoded information in romance texts.

The fifth and sixth themes identified in the essays are most germane to adoption. The fifth theme is that romance novels celebrate life with a deep-rooted optimism in happy endings. Of particular note is the comment that "the celebration of life is expressed also in the frequency with which happy endings include the birth of a child. Babies are always treated as a cause for joy in romance, whether a writer has chosen to have children or not, whether she is in favor of abortion rights or not." The sixth theme is reader identification with both the hero and heroine as the romance progresses, sometimes identifying with both simultaneously, sometimes alternately. Editor and compiler Jayne Anne Krentz concludes, "For those who understand the encoded information in the stories, the books preserve elements of ancient myths and legends that are particularly important to women. They celebrate female 


\section{FEATURE}

power, intuition, and a female worldview that affirms life and expresses hope for the future."12

\section{Similarities and Differences between Fictional and Factual Narratives}

There are similar themes and issues in all adoption narratives, whether fictional or factual, such as secret babies, identity, kinship, loss, search, reunion, and reconciliation. Romance fiction usually privileges conventional heterosexual marriage; true adoption narratives privilege the importance of blood relationships. Besides this difference and the fact that one type of narrative is fiction and the other nonfiction, the other main difference is that while romance fiction is construed within conventional and predictable reader expectations of a fairy-tale happy ending, real-life adoption reunions can be very unpredictable. ${ }^{13}$ Adoptees who search want truth, not fairy-tale endings, because their fantasies may be worse than what they may find, regardless of what that is..$^{14}$ As one author puts it, "few adoption reunions are simply happy endings; they are often fraught beginnings." ${ }^{15}$ Since romance readers demand a happy ending, anything they learn about real-life adoption searching in the reading process can definitely be presumed to be "accidental."

The gendered nature of romances as a subcategory of "women's fiction" should be noted, since it also overlaps with adoption. Romances are written and read primarily by women, and adoption search and reunion activities are also dominated by women. Similarities between romance narratives and adoption in real life break down though, since a real-life unplanned pregnancy might suggest anything but a happy ending for the pregnant woman. One need only to read a memoir like Roessle's Second-Chance Mother, which is about a very difficult birth mother-birth son reunion, or the overwhelming disappointment of Steve Pemberton's search, to appreciate the difference between real-life adoption search and reunion and its counterparts in romance fiction. The optimistic romance notion of a happy ending, even with the arrival of an unplanned pregnancy, is a notable contrast. ${ }^{16}$

\section{METHODS}

Using Ross's finding-without-seeking analytical framework, this study attempts to describe through topical textual analysis how true adoption search and reunion issues are presented in a sampling of romance fiction stories about secret babies, by answering the following questions:

1. How have the adoption reunion storylines been used within the context of the overall romance narrative?

2. How do the fictional stories compare to true adoption reunion narratives?

3. Has the development of adoption reunion themes in romance novels paralleled the development of the adoption rights movement in the United States?
A convenience sample of 129 romance fiction titles was generated through the investigator's own reading, ongoing perusal of Romance \$ells (a quarterly catalog of upcoming romance releases for booksellers and librarians), a monthly search of reviews in Romantic Times, queries on several romance online lists, a search on Goodreads, and the assistance of a secondhand romance fiction bookseller and several romance authors with knowledge of the project. To be included, the book had to (1) involve an actual adoption reunion search, regardless of which person in the adoption triad initiated it; (2) include a reunion, or at least an identification of someone deceased as the person sought; and (3) be published as a romance, or be written by a notable author associated with the romance fiction genre.

The titles were then organized into various categories, both bibliographic and plot-driven: author, title, publisher, date, who was searching, who was searched for, the gender of the searcher, the gender of the protagonist, and the love interest of the protagonist. From these categories, an overall statistical portrait of the sample was compiled, followed by an analysis of individual texts to gather exemplars of how adoption reunions were depicted by various authors. Lists of the sample and subsample titles are appended.

\section{FINDINGS AND DISCUSSION}

The 129 romances studied, published between 1978 and 2013, are cumulatively described in table 1 .

The final sample was pared down to 129 titles from the original 160 collected using a strict definition for inclusion, suggesting that adoption stories, whether they involve a reunion or not, are not necessarily rare within the romance genre. This is not surprising, given the almost classic status of the secret baby trope within romance fiction, but also it must be noted that the predominance of female searchers in the stories lends itself well to a genre that emphasizes female protagonists with a strong appeal for female readers. This female predominance also mirrors real-life adoption search narratives, as Herman points out: "One thing that has changed very little in adoption narratives is the female voice. Stories by male adoptees and adoptive fathers are rare, and birth fathers' stories are even rarer. Adoption memoirs are still overwhelming[ly] authored by women., 17

While most of the stories are single titles published by Harlequin, some authors do write multiple books on adoption reunion themes-Anna Adams, Georgia Bockoven, Annette Broadrick, Sandra Brown, Marie Ferrarella, Lisa Jackson, Arlene James, Janice Kay Johnson, Susan Mallery, Jule McBride, Tara Taylor Quinn, Dani Sinclair, and Ruth Wind. In some cases the books are deliberately produced as a series, like Annette Broadrick's, for example, in which each book is about one of three triplets separated at birth, or Gina Ferris's Family Found series (also published under the name Gina Wilkins) about the separately recounted reunions of seven siblings separated at birth. But most others are 
Table 1. Description of Sample and Findings $(N=129$ titles)

\begin{tabular}{|c|c|c|c|c|c|c|c|}
\hline \multicolumn{2}{|l|}{ Publisher } & \multicolumn{2}{|l|}{ Searcher } & \multicolumn{2}{|c|}{ Person Found } & \multicolumn{2}{|c|}{ Love Interest } \\
\hline Harlequin $^{1}$ & 110 & Birth mother & 48 & Birth daughter & 39 & Birth father & 19 \\
\hline \multirow[t]{8}{*}{ Other } & 19 & Birth daughter & 25 & Birth mother & 25 & Adopted father & 19 \\
\hline & & Birth father & 18 & Birth son & 25 & Birth relative & 12 \\
\hline & & Birth sister & 11 & Birth siblings & 13 & Adopted mother & 9 \\
\hline & & Birth son & 8 & Birth parents/family & 13 & Spouse $^{2}$ & 8 \\
\hline & & Birth parents (together) & 3 & Birth father & 5 & Birth mother & 5 \\
\hline & & Birth brother & 1 & Birth granddaughter & 1 & Subtotal & 72 \\
\hline & & Adopted parent/relative & 12 & Other & 8 & Other ${ }^{3}$ & 52 \\
\hline & & Private Investigator & 3 & & & & \\
\hline TOTAL & 129 & & 129 & & 129 & & 129 \\
\hline
\end{tabular}

1. Includes all Harlequin imprints: Harlequin Silhouette, Mira, and Steeple Hill.

2. Some stories involve husbands and wives experiencing a reunion or a reunion-induced disclosure of an adoption for the first time, which strains their marriages. In these books, the romance is the recommitment of the affected spouses after they have dealt with the reunion occurrence.

3. These love interests fall outside the adoption triad. Examples include private investigators, law enforcement officers, teachers, social workers, doctors, high school sweethearts, neighbors, and strangers encountered, such as a motel owner in one case.

stand-alone titles, even if the stories within the book involve siblings, such as Sisters Found by Joan Johnston. ${ }^{18}$ Whether any of the sample authors is herself a member of the adoption triad (birth parent, adoptive parent, or adoptee) is unknown without further investigation.

Since adoption is fraught with kinship issues and implications for the definition of family, the love interests in these books are revealing. The protagonist is expected to fall in love in a romance, and given the fact that many of these books are "category" romances with strict length limitations, that is, "published in clearly delineated categories, with a certain number of books being published in each category every month," the availability of a potential love interest is limited to a reduced number of characters to be selected from among those found or those who help with the search. ${ }^{19}$

While reunion with the other birth parent is common, the number of widowed (and therefore available) adoptive parents can seem like a convenient contrivance, and the frequency with which private investigators and law enforcement officers fall for searchers possibly exceeds credulity outside the confines of any individual story. Of particular interest are the spouses who have to overcome the family and relationship disruption of a reunion. For example, in Jennifer Greene's Born in My Heart, Ann, the menopausal adoptive mother suffering from empty nest syndrome, has to grit her teeth to appear happy for her daughter's reunion, when she actually feels frumpy, threatened, and rejected, an outsider in her daughter's life- a state not lost on her husband Jay, who is feeling that he's lost his wife emotionally while suffering for her vicariously. Their finding each other again after the reunion makes an exquisitely told love story. ${ }^{20}$ The reconciled spouse story has a more difficult, and possibly more realistic, telling in Robin Lee Hatcher's First
Born, where it takes a long time for the husband to forgive his wife's deception. ${ }^{21}$

The happy ending mandated by the conventions of romance fiction creates a general level of implausibility and optimism in this genre, both greatly desired by its fan readers, if unrealistic in the real-life adoption reunion context. Tara Taylor Quinn's Sara's Son is especially noteworthy in this regard. Her adult birth son finds Sara, who surrendered him after getting pregnant through being raped at a party in high school by three boys. The son is a cop and helps her solve a mystery about the rape. Over the course of their investigation, she falls in love with one of the men accused and convicted of raping her, who turns out to have been drugged at the time, but is also proven to be her son's birth father. He is exonerated as a sex offender before they marry. The book is unusual not only for the love interest, but also because of the noted objection of romance readers to rape in the genre. ${ }^{22}$

One aspect of these stories that is totally congruent with real-life adoption narratives is the overwhelming presence of secrets and deception, whether keeping knowledge of the conception and birth of a child from the birth father, as in Margaret Daley's A Daughter for Christmas; telling the birth mother that the child died when she was actually placed for adoption, as in Leandra Logan's Happy Birthday, Baby and Terese Ramin's Her Guardian Agent; the actual placement of the surrendered child with people different than those told to the birth mother, as in Kathleen Creighton's One More Knight or Christine Flynn's A Father's Wish; the deceptive relationship of the birth mother as "aunt" to the birth child, as in Rebecca Daniels's Father Figure and Susan Wiggs's Home Before Dark; or that the adoptee was actually kidnapped as a baby, as in Nora Roberts's Birthright. ${ }^{23}$

In addition to deception and secrets, however, an amazing 


\section{FEATURE}

array of plot devices are employed. These range from the mundane to the preposterous, extending well beyond the most common situation of starting to search after discovering one is adopted after the adoptive parents die, as in Rebecca Stratton's Lost Heritage or Gina Ferris's Full of Grace. These include, for example, a birth father tracking down the woman inseminated with his sperm in Pamela Toth's The Baby Legacy; finding or protecting various family members from Mob connections in Patricia Potter's Twisted Shadows and Catherine Anderson's Without a Trace; discovering that one is the long-lost child of an affluent family in Phyllis A. Whitney's Woman without a Past, or the descendant of a famous jazz singer in Ruth Wind's In the Midnight Rain; birth parents disguising themselves and their motives to be near their adopted birth children in Margaret Daley's A Daughter for Christmas or Lynn Erickson's Laurel and the Lawman; health crises involving a need for bone marrow transplants in Bonnie K. Winn's Family Found and Andrea Edwards's On Mother's Day; and adoptive parents threatened (at first) by impending or real reunions such as Jennifer Taylor's The Consultant's Adopted Son. ${ }^{24}$ About the only adoption reunion issues not included among the stories are synchronicity, genetic sexual attraction, and any mention of adoption reunion registries such as Soundex. ${ }^{25}$

\section{CONCLUSION}

The actual number of published romances that deal with adoption in some way, not just reunions, is unknown, although obviously larger than the definition-restricted sample studied here. Thus it is difficult to claim with any certainty that this topic has overwhelming popularity and demand among romance readers, although it is clear that secret babies do, given the persistence of the trope in the genre. The thirty-five-year span of publication dates in the sample leads to an average of four books a year specifically on adoption reunion themes during that time. Further inquiry gleaned from editors' records reveals that Harlequin published 909 secret baby books, variously called by editors "plots with secret baby," "secret child," "secret baby/ child," and "secret pregnancy" from 1981 to 2013, which averages twenty-eight per year. While this seems a very small percentage of overall Harlequin publishing production, since publishing output totaled 1,320 titles in 2013 alone, the consistent production of these types of stories over that time period is noteworthy not only to demonstrate the enduring popularity of the trope but also of adoption reunion themes. ${ }^{26}$

Without comparable records before 1978, it is impossible to claim that adoption reunion romance stories have grown in tandem with the adoptee rights movement and the growth of publicity about adoptee search and reunions on shows such as Pamela Slayton's on the Oprah Winfrey network. If anything, the current study just shows the persistence of the secret baby trope and the consistent percentage of secret baby books on adoption reunion themes over the specific time period studied. Histories of Mills and Boon, the UK publisher acquired by the more recently established Harlequin in 1971, are unfortunately not specific enough on this topic to determine the status of secret baby books prior to the period sampled. ${ }^{27}$ If records exist, possibly somewhere in the paper archives of Mills and Boon at Reading University in the United Kingdom, this comparison would be warranted in future studies to answer the question of the growth of and changes within the trope over time, even if the specific question of the growth of adoption-themed secret baby books may still not be answerable.

What these books seem to demonstrate is what Snitow recognized, despite her otherwise scorn for the genre and its readers, which is that romance novels "reflect ... commonly experienced psychological and social elements in the daily lives of women . . . [and] may well be closer to describing women's hopes for love than the work of fine women novelists." ${ }^{28}$ Beyond Snitow's observations, though, many of the books on this theme echo what romance author Jennifer Greene, one of whose stories is included in the sample, says: "I have always believed that the romance field has a choice to be less about romance and more about love/what real love means/what real love takes to survive and thrive. In an ideal world, adoption and reunion stories would use that 'power' to reach readers in a positive constructive way." 29 Moreover, in the context of adoption searches, which like love and romance in real life, can be fraught with confusion, uncertainty, and disappointment, the searchers in romance books win. Even if they cannot find the person they are looking for, they find love and acceptance. Readers of the romance genre in general, and these books in particular, can hardly be faulted for enjoying such stories, even as they themselves recognize that many of them are pure fantasy. ${ }^{30}$

Through their strong emotional appeal, adoption reunion stories mirror many real-life adoption reunion stories in fact, albeit with the imposition of a requisite happy ending. In doing so, they also provide yet another topical touchstone for what the romance genre has always done well: provide a momentary escape from real life, while offering reassurance and wish fulfillment to women readers on a serious topic of great resonance in their lives.

In terms of information-seeking, adoption reunion romances do provide in the aggregate mostly the same information on adoption searching as that recounted in true memoirs and adoption search manuals, even if the information is not the primary reason for reading the books, and even if the accurate factual information is framed by romance conventions. What is missing from this textual study and might be the topic of future studies is the reader response to the information incidentally provided. Possibilities might be validation of feelings, help with accepting a situation unable to be changed, getting the courage to make a change, or just increasing empathy for women who have surrendered children, or for their children. Regardless, 
adoption reunion romances provide a rich trove for future research in this area.

\section{References}

1. Carol J. Stephenson, "The Anatomy of the Secret Baby," Florida Romance Writers (archived newsletters) (1999), http://www.sme delstein.com/creative/frw/anatomyl.htm; Tori Benson, "Package Deals: The Appeal of Ready-Made Families in Romance," Heroes and Heartbreakers (blog), September 2012, http://www .heroesandheartbreakers.com/blogs/2012/09/package-deals -the-appeal-of-ready-made-families-in-romance.

2. Emilie Richards, All Those Years Ago (New York: Silhouette Books, 1991).

3. David Elsweiler, Max L. Wilson, and Brian Kirkegaard Lunn, "Understanding Casual-Leisure Information Behaviour," in New Directions in Information Behaviour, Library and Information Science, Volume 1, ed. Amanda Spink and Jannica Heinström (Bingley, West Yorkshire, UK: Emerald Group, 2011): 211-41; Jarkko Kari and Jenna Hartel, "Information and Higher Things in Life: Addressing the Pleasurable and the Profound in Information Science," Journal of the American Society for Information Science and Technology 58, no. 8 (2007): 1141-47.

4. Catherine Sheldrick Ross, "A Model for the Process of Choosing a Book for Pleasure" (Handout) Public Library Association Spring Symposium, Chicago, 1999; Kamy Ooi and Chern Li Liew, "Selecting Fiction as Part of Everyday Life InformationSeeking," Journal of Documentation 67, no. 5 (2012): 748-72; Joyce G. Saricks, Readers' Advisory Service in the Public Library, 3rd ed. (Chicago: American Library Association, 2005); The Secret Language of Books: A Guide to Appeal (Durham, NC: NoveList, 2017), https://www.ebscohost.com/uploads/novelist/ pdf/NoveList_Appeal_2017.pdf; Keren Dali, "From Book Appeal to Reading Appeal: Redefining the Concept of Appeal in Readers' Advisory," Library Quarterly 84, no. 1 (January 2014): 22-48.

5. Catherine Sheldrick Ross, "Finding without Seeking: The Information Encounter in the Context of Reading for Pleasure," Information Processing and Management 35 (1999): 783-99.

6. Marianne Novy, Reading Adoption: Family and Difference in Fiction and Drama (Ann Arbor: University of Michigan Press, 2005); Margaret Homans, Imprint of Another Life: Adoption Narratives and Human Possibility (Ann Arbor: University of Michigan Press, 2013).

7. Pamela Regis, A Natural History of the Romance Novel (Philadelphia: University of Pennsylvania Press, 2003), 9-16.

8. A. Dana Ménard, "Note from the Field: Reflecting on Romance Novel Research: Past, Present and Future," Journal of Popular Romance Studies 3, no. 2 (June 14, 2013), http://jprstudies. org/2013/06/note-from-the-field-reflecting-on-romance-novel -research-past-present-and-future-by-a-dana-menard/.

9. Ann Barr Snitow, "Mass Market Romance: Pornography for Women Is Different," Radical History Review, no. 20 (Spring/ Summer 1979): 142-43.

10. Elsweiler, Wilson, and Lunn, "Understanding Casual-Leisure Information Behaviour," 211-41; Kari and Hartel, "Information and Higher Things in Life," 1141-47.

11. Janice Radway, Reading the Romance (Chapel Hill: The University of North Carolina Press, 1991), 209.

12. Jayne Ann Krentz, ed., Dangerous Men and Adventurous Women: Romance Writers on the Appeal of the Romance (Philadelphia: University of Pennsylvania Press. 1992), 7-8.

13. Linda J. Lee, "Guilty Pleasures: Reading Romance Novels as Reworked Fairy Tales," Marvels and Tales 2, no. 1 (2008): 52-56; Janet Carsten, "Knowing Where You've Come From: Ruptures and Continuities of Time and Kinship in Narratives of Adoption Reunions," Journal of the Royal Anthropological Institute 6, no. 4 (2000): 687-703; Evelyn Robinson, Adoption Reunion: Ecstasy or Agony? (Christies Beach, South Australia: Clova Publications, 2009).

14. Jayne Schooler, Searching for a Past: The Adopted Adult's Unique Process of Finding Identity (Colorado Springs: Pinon Press, 1995).

15. Susan Dominus, "Adoption, Reunion, Connection," Big City, New York Times, August 6, 2010, http://www.nytimes. com/2010/08/07/nyregion/07bigcity.html.

16. Denise Roessle, Second-Chance Mother: A Memoir (Tsu T'ina, Canada: Red Willow, 2011); Steve Pemberton, A Chance in the World (Nashville: Thomas Nelson, 2012).

17. Ellen Herman, "Adoption Narratives," The Adoption History Project, Department of History, University of Oregon, last updated February 24, 2012, http://darkwing.uoregon. edu/ adoption/topics/adoptionnarratives.htm.

18. Joan Johnston, Sisters Found (Don Mills, Ontario: Mira, 2002).

19. "Category Romance," RomanceWiki, last modified January 3, 2012, 20:51, http://www.romancewiki.com/Category_Romance.

20. Jennifer Greene, Born in My Heart (Don Mills, Ontario: Harlequin, 2007).

21. Robin Lee Hatcher, First Born (Carol Stream, IL: Tyndale House, 2002).

22. Tara Taylor Quinn, Sara's Son (Don Mills, Ontario: Harlequin, 2007); Radway, Reading the Romance, 74.

23. Margaret Daley, A Daughter for Christmas (Don Mills, Ontario: Harlequin, 2010); Leandra Logan, Happy Birthday, Baby (Don Mills, Ontario: Harlequin, 1994); Terese Ramin, Her Guardian Agent (New York: Silhouette, 2001); Kathleen Creighton, One More Knight (New York: Silhouette, 1998); Christine Flynn, A Father's Wish (New York: Silhouette, 1995); Rebecca Daniels, Father Figure (New York: Silhouette, 1996); Susan Wiggs, Home Before Dark (Don Mills, Ontario: Mira, 2003); Nora Roberts, Birthright (New York: Putnam, 2003).

24. Rebecca Stratton, Lost Heritage (Don Mills, Ontario: Harlequin, 1978); Gina Ferris, Full of Grace (New York: Silhouette, 1993); Pamela Toth, The Baby Legacy (New York: Silhouette, 2000); Patricia Potter, Twisted Shadows (New York: Jove, 2003); Catherine Anderson, Without a Trace (Don Mills, Ontario: Harlequin, 1989); Phyllis Whitney, Woman without a Past (New York: Fawcett, 1991); Ruth Wind, In the Midnight Rain (New York: Harpertorch, 2000); Margaret Daley, A Daughter for Christmas (Don Mills, Ontario: Harlequin, 2010); Lynn Erickson, Laurel and the Lawman (Don Mills, Ontario: Harlequin, 1994); Bonnie Winn, Family Found (Don Mills, Ontario: Harlequin, 2001); Andrea Edwards, On Mother's Day (New York: Silhouette, 1996); Jennifer Taylor, The Consultant's Adopted Son (Don Mills, Ontario: Harlequin, 2006).

25. LaVonne H. Stiffler, Synchronicity and Reunion: The Genetic Connection of Adoptees and Birthparents (LaVonne Stiffler, 1992); Susan Donaldson James, "Adoptees Who Reunite with Lost Parent Risk Genetic Sexual Attraction," Good Morning America, May 17, 2012, https://gma.yahoo.com/adoptees-reunite-lost -parent-risk-genetic-sexual-attraction-203754464--abc-news -wellness.html; International Soundex Reunion Registry, http:// www.isrr.org.

26. Don Lucey, e-mail message to author, January 27, 2014.

27. Jay Dixon, The Romance Fiction of Mills $\&$ Boon, 1909-1990s (London: UCL Press. 1999); Laura Vivanco, For Love and Money: The Literary Art of the Harlequin Mills \& Boon Romance, HumanitiesEbooks Genre Fiction Monographs Series, edited by John Lennard (Tirril, Penrith: Humanities-Ebooks LLP, 2011); Joseph McAleer, Passion's Fortune: The Story of Mills and Boon (Oxford: Oxford University Press, 1999).

28. Snitow, "Mass Market Romance," 143, 160.

29. Jennifer Greene, e-mail message to author, February 27, 2014.

30. Doreen Owens Malek, "Mad, Bad and Dangerous to Know: The Hero as Challenge," in Krentz, Dangerous Men and Adventurous Women, 74-75. 


\section{FEATURE}

\section{APPENDIX A. TITLES IN THE SAMPLE EXAMINED}

\begin{tabular}{|c|c|c|c|c|c|c|c|}
\hline Abbot, Laura & This Christmas & Harlequin & 1996 & Erickson, Lynn & Laurel and the Lawman & Harlequin & 1994 \\
\hline Adams, Anna & Her Daughter's Father & Harlequin & 2000 & Evans, Ann & Home to Stay & Harlequin & 1998 \\
\hline Adams, Anna & The Prodigal Cousin & Harlequin & 2004 & Faith, Barbara & Echoes of Summer & Silhouette & 1991 \\
\hline Adams, Kat & Thursday's Child & Silhouette & 1993 & Ferrarella, Marie & Heroes Great and Small & Silhouette & 1993 \\
\hline $\begin{array}{l}\text { Alexander, } \\
\text { Carrie }\end{array}$ & A Family Christmas & Harlequin & 2004 & Ferrarella, Marie & $\begin{array}{l}\text { Desperately Seeking } \\
\text { Twin... }\end{array}$ & Silhouette & 1997 \\
\hline \multirow{2}{*}{$\begin{array}{l}\text { Alsobrook, } \\
\text { Rosalyn }\end{array}$} & \multirow[t]{2}{*}{ Questing Heart } & \multirow[t]{2}{*}{ Harlequin } & \multirow[t]{2}{*}{1991} & Ferrarella, Marie & Baby Came C.O.D. & Silhouette & 1997 \\
\hline & & & & Ferrarella, Marie & Holding Out for a Hero & Silhouette & 1993 \\
\hline \multirow{2}{*}{$\begin{array}{l}\text { Anderson, } \\
\text { Catherine }\end{array}$} & \multirow[t]{2}{*}{ Without a Trace } & \multirow[t]{2}{*}{ Harlequin } & 1989 & Ferris, Gina & Full of Grace & Silhouette & 1993 \\
\hline & & & 1986 & Field, Sandra & The Mother of His Child & Harlequin & 1999 \\
\hline Anzelon, Robyn & Searching & Harlequin & \multirow{2}{*}{1996} & Flynn, Christine & A Father's Wish & Silhouette & 1995 \\
\hline $\begin{array}{l}\text { August, } \\
\text { Elizabeth }\end{array}$ & $\begin{array}{l}\text { The Rancher and the } \\
\text { Baby }\end{array}$ & Silhouette & & Fossen, Delores & Undercover Daddy & Harlequin & 2007 \\
\hline \multirow{2}{*}{$\begin{array}{l}\text { Baxter, Mary } \\
\text { Lynn }\end{array}$} & \multirow[t]{2}{*}{ Sweet Justice } & \multirow[t]{2}{*}{ Warner } & \multirow[t]{2}{*}{1994} & Frazier, Amy & Celebrate the Child & Silhouette & 1999 \\
\hline & & & & Frazier, Amy & The Secret Baby & Silhouette & 1995 \\
\hline Benjamin, Nicki & My Baby, Your Child & Silhouette & 1994 & Garrett, Sally & Desert Star & Harlequin & 1989 \\
\hline Blackstock, Terri & Never Again Goodbye & Zondervan & 1996 & Glenn, Victoria & One of the Family & Silhouette & 1987 \\
\hline \multirow{2}{*}{$\begin{array}{l}\text { Bockoven, } \\
\text { Georgia }\end{array}$} & \multirow[t]{2}{*}{ An Unspoken Promise } & \multirow[t]{2}{*}{ Harper } & \multirow[t]{2}{*}{1997} & Gordon, Lucy & This Is My Child & Silhouette & 1996 \\
\hline & & & & Greene, Jennifer & Born in My Heart & Harlequin & 2007 \\
\hline $\begin{array}{l}\text { Bockoven, } \\
\text { Georgia }\end{array}$ & $\begin{array}{l}\text { A Marriage of } \\
\text { Convenience }\end{array}$ & Harper & 1991 & $\begin{array}{l}\text { Halldurson, } \\
\text { Phyllis }\end{array}$ & Father in the Middle & Silhouette & 1995 \\
\hline Boswell, Barbara & Sensuous Perception & Bantam & 1984 & Hannay, Barbara & Adopted: Outback Baby & Harlequin & 2008 \\
\hline Bowen, Judith & $\begin{array}{l}\text { Like Father, Like } \\
\text { Daughter }\end{array}$ & Harlequin & 1998 & $\begin{array}{l}\text { Hatcher, Robin } \\
\text { Lee }\end{array}$ & Firstborn & Tyndale & 2002 \\
\hline $\begin{array}{l}\text { Broadrick, } \\
\text { Annette }\end{array}$ & Too Tough to Tame & Silhouette & 2003 & Jackson, Brenda & Slow Burn & St. Martin's & 2007 \\
\hline Broadrick, & MacGowan Meets His & Silhouette & 2003 & Jackson, Lisa & $D$ is for Dani's Baby & Silhouette & 1995 \\
\hline Annette & Match & & & Jackson, Lisa & Wishes & Zebra & 1995 \\
\hline Brown, Sandra & A Treasure Worth & Warner & 1982 & James, Arlene & Child of Her Heart & Silhouette & 1995 \\
\hline & Seeking & & & James, Arlene & Baby Boy Blessed & Silhouette & 1994 \\
\hline Brown, Sandra & A Secret Splendor & Silhouette & 1983 & Jensen, Muriel & Bridge to Yesterday & Harlequin & 1991 \\
\hline Cameron, Stella & Finding Ian & Zebra & 2001 & Johnson, Janice & Lost Cause & Harlequin & 2006 \\
\hline Carroll, Marisa & Gathering Place & Harlequin & 1988 & & & & \\
\hline $\begin{array}{l}\text { Collins, Mary } \\
\text { Smith }\end{array}$ & Baby Makes Three & Silhouette & 1996 & $\begin{array}{l}\text { Johnson, Janice } \\
\text { Kay }\end{array}$ & Open Secret & $\begin{array}{l}\text { Mills and } \\
\text { Boon }\end{array}$ & 2007 \\
\hline Creighton, & One More Knight & Silhouette & 1998 & Johnston, Joan & Sisters Found & Mira & 2002 \\
\hline Katl & & & & Kaiser, Janice & Lotus Moon & Harlequin & 1986 \\
\hline Daley, Margaret & $\begin{array}{l}\text { A Daughter for } \\
\text { Christmas }\end{array}$ & Harlequin & 2010 & \begin{tabular}{|l|} 
Kaiser, Janice \\
\end{tabular} & The Big Secret & Harlequin & 1992 \\
\hline Dalton, Margot & A Family Likeness & Harlequin & 1996 & Kay, Patricia & Family Album & Berkley & 2002 \\
\hline Daniels, Kayla & Her First Mother & Silhouette & 1998 & Laurence, Anne & Remember When & Harlequin & 1993 \\
\hline Daniels, Rebecca & Father Figure & Silhouette & 1996 & Leigh, Allison & Hard Choices & Silhouette & 2003 \\
\hline Darcy, Emma & Merry Christmas & Harlequin & 1997 & Logan, Leandra & Happy Birthday, Baby & Harlequin & 1994 \\
\hline David, Kay & Desperate & Silhouette & 1995 & $\begin{array}{l}\text { Lohmann, } \\
\text { Jennifer }\end{array}$ & First Move & Harlequin & 2013 \\
\hline De Vita, Sharon & The Marriage Promise & Silhouette & 2000 & Major, Ann & A Knight in Tarnished & Silhouette & 1992 \\
\hline Duncan, Judith & Better than Before & Silhouette & 1992 & & & & \\
\hline Edwards, Andrea & On Mother's Day & Silhouette & 1996 & Mallery, Susan & Already Home & Mira & 2011 \\
\hline
\end{tabular}


Searching for Birth Parents or Adopted Children

\begin{tabular}{|c|c|c|c|}
\hline Mallery, Susan & Their Little Princess & Silhouette & 2000 \\
\hline Mallery, Susan & Cowboy Daddy & Silhouette & 1994 \\
\hline Marton, Sandra & Roarke's Kingdom & Harlequin & 1991 \\
\hline McBride, Jule & Verdict: Parenthood & Harlequin & 1997 \\
\hline McBride, Jule & Mission: Motherhood & Harlequin & 1997 \\
\hline $\begin{array}{l}\text { McKenna, } \\
\text { Lindsay }\end{array}$ & Shadows from the Past & Harlequin & 2009 \\
\hline McLinn, Patricia & $\begin{array}{l}\text { A Stranger in the } \\
\text { Family }\end{array}$ & Silhouette & 1995 \\
\hline Merritt, Jackie & The Secret Daughter & Silhouette & 1998 \\
\hline $\begin{array}{l}\text { Mignerey, } \\
\text { Sharon }\end{array}$ & Too Close for Comfort & Silhouette & 2001 \\
\hline Mikels, Jennifer & Child of Mine & Silhouette & 1995 \\
\hline Molay, Mollie & Like Father, Like Son & Harlequin & 1996 \\
\hline $\begin{array}{l}\text { Monroe, Mary } \\
\text { Alice }\end{array}$ & The Four Seasons & Mira & 2001 \\
\hline Morse, Nancy & A Child of His Own & Silhouette & 1997 \\
\hline Novak, Brenda & Taking the Heat & Harlequin & 2003 \\
\hline $\begin{array}{l}\text { O'Brien, } \\
\text { Kathleen }\end{array}$ & The Homecoming Baby & Harlequin & 2004 \\
\hline Paige, Laurie & The One and Only & Silhouette & 2003 \\
\hline $\begin{array}{l}\text { Palmer, } \\
\text { Catherine }\end{array}$ & For the Love of a Child & Silhouette & 1994 \\
\hline Perry, Marta & $\begin{array}{l}\text { Desperately Seeking } \\
\text { Dad }\end{array}$ & Steeple Hill & 2000 \\
\hline $\begin{array}{l}\text { Pickart, Joan } \\
\text { Elliott }\end{array}$ & Mac Allister's Return & Silhouette & 2005 \\
\hline Potter, Patricia & Twisted Shadows & Jove & 2003 \\
\hline $\begin{array}{l}\text { Quinn, Tara } \\
\text { Taylor }\end{array}$ & The Rancher's Bride & Harlequin & 2001 \\
\hline $\begin{array}{l}\text { Quinn, Tara } \\
\text { Taylor }\end{array}$ & The Birth Mother & Harlequin & 1996 \\
\hline $\begin{array}{l}\text { Quinn, Tara } \\
\text { Taylor }\end{array}$ & Sara's Son & Harlequin & 2007 \\
\hline Ramin, Terese & Her Guardian Agent & Silhouette & 2001 \\
\hline Ray, Francis & When Morning Comes & St. Martin's & 2012 \\
\hline Reavis, Cheryl & A Crime of the Heart & Silhouette & 1988 \\
\hline Richards, Emilie & All Those Years Ago & Silhouette & 1991 \\
\hline Richer, Lois & Blessed Baby & Steeple Hill & 2001 \\
\hline
\end{tabular}

\begin{tabular}{|c|c|c|c|}
\hline $\begin{array}{l}\text { Riggs, Paula } \\
\text { Detmer }\end{array}$ & Daddy by Choice & Silhouette & 2000 \\
\hline $\begin{array}{l}\text { Riggs, Paula } \\
\text { Detmer }\end{array}$ & Taming the Night & Fawcett & 1999 \\
\hline $\begin{array}{l}\text { Rinehold, } \\
\text { Connie }\end{array}$ & Silken Threads & Harlequin & 1989 \\
\hline Roberts, Kelsey & Her Mother's Arms & Harlequin & 1998 \\
\hline Roberts, Nora & Birthright & Putnam & 2003 \\
\hline Ross, JoAnn & No Regrets & Mira & 1997 \\
\hline Sharpe, Isabel & You Belong to Me & Harlequin & 2009 \\
\hline Shay, Kathryn & Michael's Family & Harlequin & 1997 \\
\hline Sinclair, Dani & $\begin{array}{l}\text { The Sheriff Gets His } \\
\text { Lady }\end{array}$ & Harlequin & 2002 \\
\hline Sinclair, Dani & Word of Honor & Harlequin & 2003 \\
\hline Sinclair, Tracy & $\begin{array}{l}\text { Does Anybody Know } \\
\text { Who Allison Is? }\end{array}$ & Silhouette & 1995 \\
\hline Spindler, Erica & Baby Mine & Silhouette & 1992 \\
\hline Stevens, Amanda & A Baby's Cry & Harlequin & 1996 \\
\hline $\begin{array}{l}\text { Stewardson, } \\
\text { Dawn }\end{array}$ & His Child or Hers? & Harlequin & 2001 \\
\hline $\begin{array}{l}\text { Stratton, } \\
\text { Rebecca }\end{array}$ & Lost Heritage & Harlequin & 1978 \\
\hline Taylor, Jennifer & $\begin{array}{l}\text { Consultant's Adopted } \\
\text { Son }\end{array}$ & Harlequin & 2006 \\
\hline Toth, Pamela & The Baby Legacy & Silhouette & 2000 \\
\hline Victor, Cindy & Kindred Spirits & Harlequin & 1987 \\
\hline Warren, Linda & Truth about Jane Doe & Harlequin & 2000 \\
\hline Warren, Pat & Nobody's Child & Silhouette & 1995 \\
\hline Wells, Robin & Still the One & Hachette & 2010 \\
\hline $\begin{array}{l}\text { Wentworth, } \\
\text { Sally }\end{array}$ & Shadow Play & Harlequin & 1994 \\
\hline Whisenand, Val & Giveaway Girl & Silhouette & 1990 \\
\hline Whitney, Phyllis & Woman without a Past & Fawcett & 1991 \\
\hline Wiggs, Susan & Home before Dark & Mira & 2003 \\
\hline Wilkins, Gina & Hardworking Man & Harlequin & 1993 \\
\hline Wind, Ruth & In the Midnight Rain & Harpertorch & 2000 \\
\hline Wind, Ruth & Last Chance Ranch & Silhouette & 1995 \\
\hline Winn, Bonnie K. & Family Found & Harlequin & 2001 \\
\hline York, Rebecca & What Child Is This? & Harlequin & 1993 \\
\hline
\end{tabular}

